\begin{tabular}{|c|c|c|}
\hline $\begin{array}{l}\text { WHOLUD } \\
\text { OUDWTLS }\end{array}$ & $\begin{array}{l}\text { Continental J. Earth Sciences } 7 \text { (1): } 40 \text { - 47, } 2012 \\
\text { (C) Wilolud Journals, } 2012 \\
\text { Printed in Nigeria }\end{array}$ & $\begin{array}{c}\text { ISSN: } 2141-4076 \\
\text { doi: } \frac{\text { http://www.wiloludjournal.com }}{10.5707 / \text { cjearthsci.2012.7.1.40.47 }}\end{array}$ \\
\hline
\end{tabular}

\title{
GEOTECHNICAL STUDY OF THE PROPERTIES OF SOILS: A CASE STUDY OF NASSARAWA - EGGON TOWN AND ENVIRONS, NORTHERN NIGERIA
}

\author{
${ }^{1}$ Stephen J. Mallo and ${ }^{2}$ Alu A.Umbugadu \\ ${ }^{1}$ Department of Geology and Mining, University of Jos, Nigeria \\ ${ }^{2}$ Department of Geology and Mining, Nasarawa State University, Keffi, Nigeria.
}

\begin{abstract}
The principal objective in geotechnical testing is to know the properties and behavior of soil as an engineering material. The performance of soil in engineering practice is greatly influenced by the natural environmental conditions and conditions imposed by construction of structures. The aim of soil testing is to obtain reasonably representative values of the soil properties that are reliable and have direct and significant bearing upon the solution of the practical problems involved especially in various aspects of civil engineering. This important more so that Nasarawa State is relatively young with high prospects for growth and development. Several representative samples taken at an average depth of $1.25 \mathrm{~m}$ have been studied within a $48 \mathrm{~km}^{2}$ area with the view of establishing geotechnical properties of the soils around Nasarawa- Eggon and its environs. The study involves some geotechnical testing of soils such as Sieve Analysis, Atterburg Limits (Liquid, Plastic and Shrinkage Limits), Consolidation, Compaction, Bulk Density, and Specific Density. The results of geotechnical testing shows Plastic Limit (PL) value of $23.70 \%$ and a corresponding Plasticity Index (PI) of $21.20 \%$. The highest bulk Density and specific gravity values of soils are $22.25 \mathrm{KN} / \mathrm{m} 2$ and 2.68 respectively while the Sieve Analysis indicates particles sizes vary between 0.1 to $1.5 \mathrm{~mm}$.
\end{abstract}

KEYWORDS: Compaction; Consolidation; Water absorption; Atterberg Limits (Liquid, Plastic and Shrinkage Limits), Plasticity Index; Bulk Density and Specific Density.

\section{INTRODUCTION}

The study area lies within Wamba Sheet 210SW in Nasarawa State of Nigeria and is located in NassarawaEggon Local Government Area (LGA). The area lies between longitude $8^{\circ} 30^{\prime} \mathrm{E}$ and $8^{\circ} 33^{\prime} 50.3^{\prime \prime} \mathrm{E}$ and latitude $8^{\circ} 41^{\prime} 9.7^{\prime \prime} \mathrm{N}$ and $8^{\circ} 45^{\prime} \mathrm{N}$ (fig. 1). The study area covers an area of about 49 square kilometres $\left(\mathrm{km}^{2}\right)$ and it is bordered politically to the North by Akwanga, to the East by Wamba, to the West by Doma and to the South by Lafia LGAs. It is accessible by a major road that links Akwanga to the state capital (Lafia). Apart from the major road, there are minor roads that criss - cross the study area, making access very easy most especially in the dry season.

Nasarawa State is relatively new having been created in 1980s. Its creation date notwithstanding, the population growth and the expansion of Nasarawa, the capital city is now expanding making the city one of the fastest growing amongst its pairs in Nigeria.

This unprecedented growth is already taking its toll on Nasarawa Eggon Town and Environs which are catchment Satellite Town and villages also with potential prospect for rapid Urbanization. The principal objective in geotechnical testing is to know the properties and behavior of soil as an engineering material. The performance of soil in engineering practice is greatly influenced by the natural environmental conditions and conditions imposed by construction of structures (Arora, 2008). The aim of soil testing is to obtain reasonably representative values of the soil properties that are reliable and have direct and significant bearing upon the solution of the practical problems involved.

In view of its rapid growth and expansion, study is expected to provide a lead to the understanding of properties of the various types of soils for the purpose of civil, agricultural and other infrastructural development, such as sewage systems, airports, recreational areas, anther public/ private municipal and submunicipal areas. It is expected also that the study shall in addition provide a clue to the capital city's Urban Geology. The study shall 
Stephen J. Mallo and Alu A.Umbugadu: Continental J. Earth Sciences 7 (1): 40 - 47, 2012

involve the some geotechnical testing of soils such as Sieve Analysis, Atterburg Limits (Liquid, Plastic and Shrinkage Limits), Consolidation, Compaction in addition to Bulk Density, and Specific Density.

\section{METHODOLOGY}

The mapping of the study area was carried out using a scale of 1:50000 topographic maps enlarged to a scale of 1:25000. This map was prepared from Wamba Sheet 210SW. positions of soil samples were ascertained from Global Positioning System (GPS) readings and fits to the corresponding latitudes and longitudes. Systematic method of sampling was adopted (using the digger and shovel because the modern sampling equipment was not easy to come by) where disturbed soil samples were collected from different locations within the study area. During the field mapping exercise, representative samples were collected weighing about a $\mathrm{Kg}$ each at a depth of about one metre, at a grid intervals of $2.5 \mathrm{~km}$ each and labelled AUS.

Several soil samples were collected and series of geological analyses were conducted in the laboratory. Such tests includes: compaction, Atterberg Limits (to determine plasticity index), consolidation test, sieve analysis, specific gravity, and density test.

\section{GEOLOGY}

The study area is part of the Mada Younger Granite Ring Complex of Nigeria. Jacobson, et al (1958), noted the occurrence of a well defined massif between Akwanga and Lafia as one of the Younger Granite Complexes of Nigeria. Apart from Afu Complex, the south Mada Hill (centred approximately at $8^{\circ} 25^{\prime} \mathrm{E}, 8^{\circ} 45^{\prime} \mathrm{N}$ ) is the most southern member of the Younger Granite Complexes of Nigeria. It lies in a NE - SW trending zone which contains the Afu Complex to the SW and some others as the Sharwai, Sha - Kuleri, Ropp, Jarawa and Zaranda to the NE. Fig.1.

Some works have been carried out around the study area which forms part of the Basement Complex of North Central Nigeria. These areas include Akwanga Sheet 209NE and NW. In 1911, Falconer was the first to carry out a geological survey, which was centred on the general geology and geography of Northern Nigeria. In his work, he differentiated the granitic rocks into Older Granites and Younger Granites based on field relations. Jacobson et al. (1958) disclosed the occurrence of the Ring Complex in the Younger Granite Province of Northern Nigeria. Macleod et al. (1971) also pointed out that much of the area is underlain by rocks of the Basement Complex which are all members of a single orogenic cycle.

Rahaman (1971, 1978), laid down some important factors as regards the geochronology and evolution of the Basement Complex of Nigeria and the classification of rocks in the Nigerian Precambrian Basement Complex. However, on a relatively larger scale, the Geological Survey of Nigeria mapped the Akwanga sheet 209 on a scale of 1:100,000.

Ajibade (1977) in his unpublished thesis, worked on the geology of the Southern part of Wamba sheet 210SW, the distribution and mineralogy of pegmatite in NW Wamba district. Wright, E. P. (1970) worked on the Basement Complex of Northern Nigeria while Oyawoye (1978) also worked on the geology of Nassarawa Eggon area in his B.Sc thesis.

The field mapping revealed that the about $48 \%$ of the study area is composed of biotite granite; $15 \%$ gneiss; $10 \%$ microgranite; $8 \%$ migmatite/schist; $5 \%$ hornblend-biotite granite and about $14 \%$ of older-granite and rhyolite Figs. $2 \& 3$. 
Stephen J. Mallo and Alu A.Umbugadu: Continental J. Earth Sciences 7 (1): 40 - 47, 2012

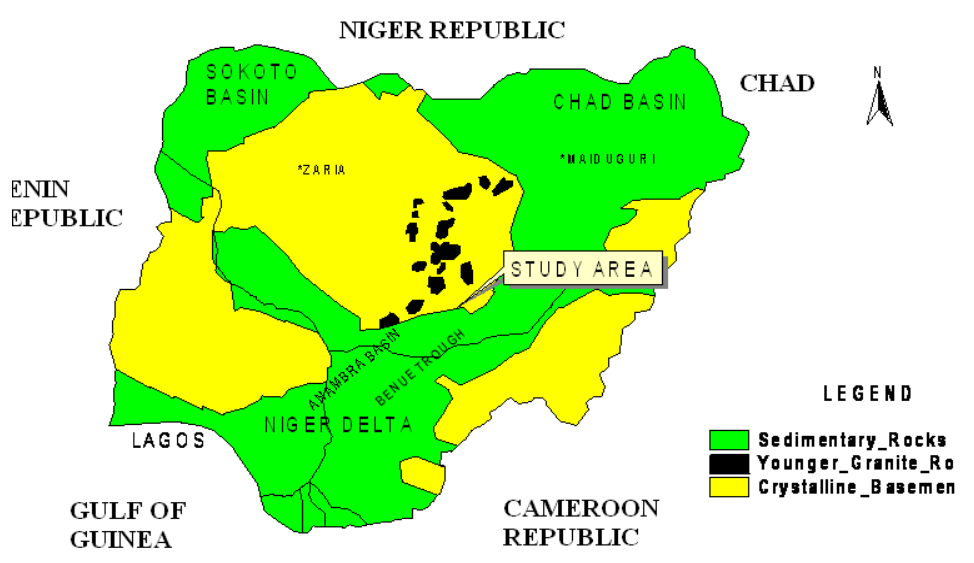

Fig 1: A Simplified Geological map of Nigeria (after kogbe, 1989)

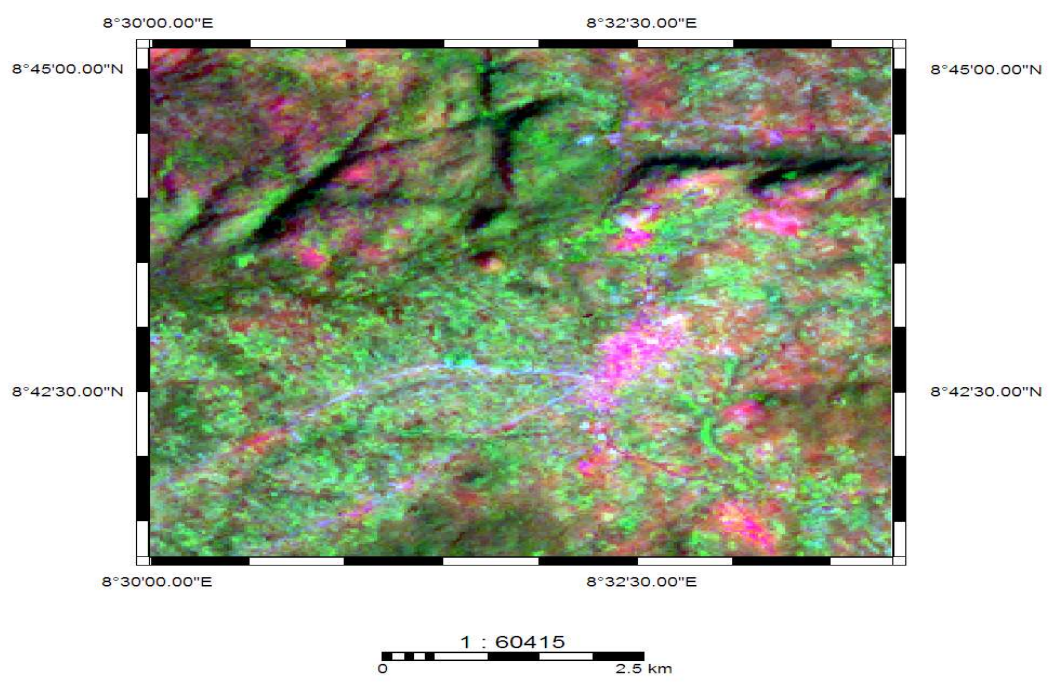

Fig. 2: Satellite Image of the Study Area 


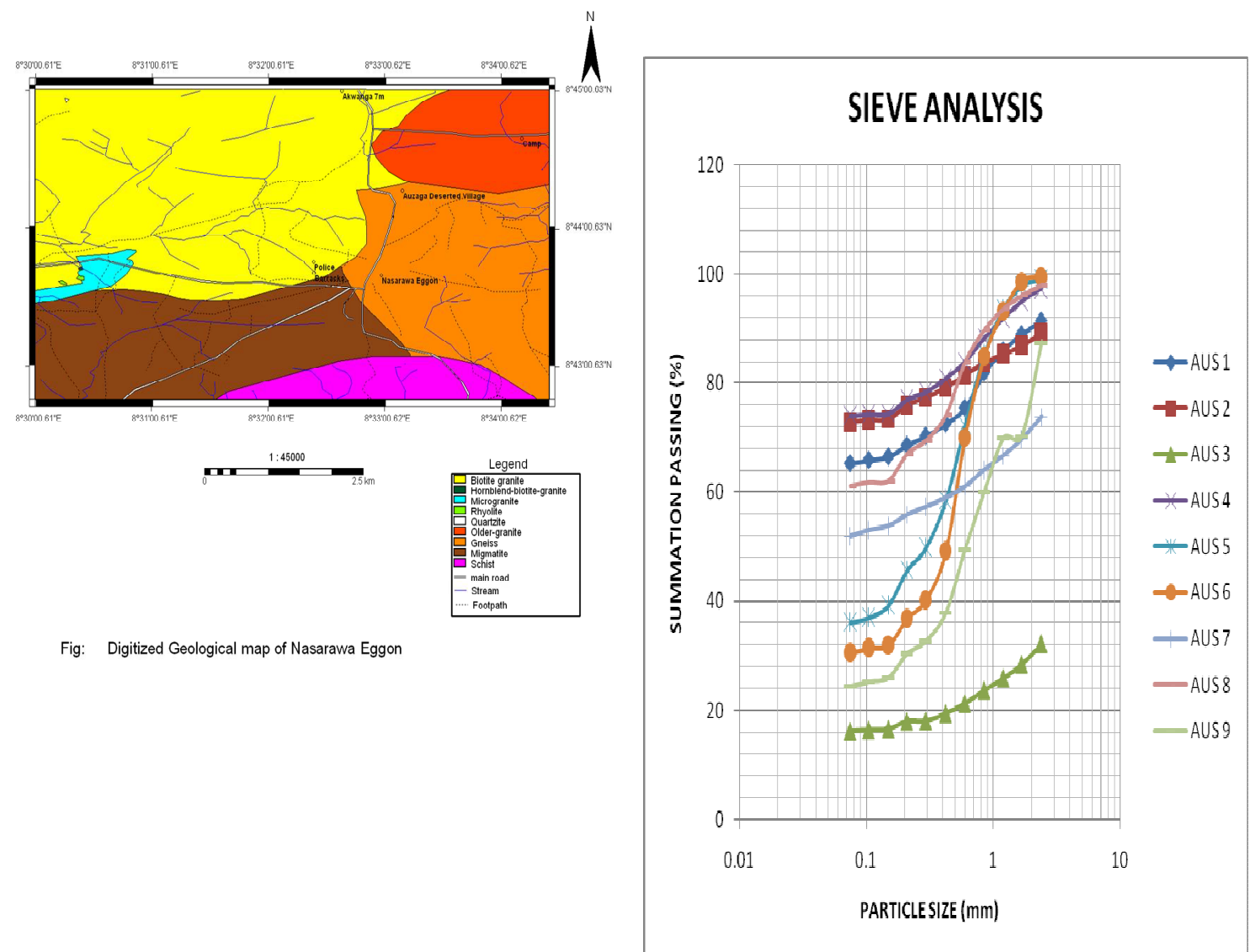

Fig.3: Digitalized Map of Nasarawa Eggon

Fig.4 Particle size distribution curve for soils of the Study Area

GEOTECHNICAL PROPERTIES OF SOILS

A Geotechnical study is a sub - discipline of geology and civil engineering that involves testing of natural materials found close to the surface of the earth. It includes the application of the principles of soil mechanics and rock mechanics to the design of foundations, retaining structures, and earth structures (Das, 2006).

Sieve Analysis: The mechanical analysis, also known as particle size analysis, is a method of separation of soils into different fractions based on the particle size. It expresses quantitatively the proportions, by mass, of various sizes of particles present in a soil. It is shown graphically on a particle size distribution curve Fig. 2 for all the representative samples. The particles sizes varies between 0.1 to $1.5 \mathrm{~mm}$

The particle size distribution curve, also known as a gradation curve, represents the distribution of particles of different sizes in the soil mass. The percentage finer (summation passing) than a given size is plotted as ordinate (on natural scale) and the particle size (aperture size) as abscissa (on log scale).

Atterberg Limits: Water content greatly affects the engineering behavior of fine-grained soils. In the order of increasing moisture content, a dry soil will transit into four distinct states: from solid state, to semisolid state, to plastic state, and to liquid state. The water contents at the boundary of these states are known as Atterberg. limits. Between the solid and semisolid states is shrinkage limit, between semisolid and plastic states is plastic limit, and between plastic and liquid states is liquid limit, Fig.5
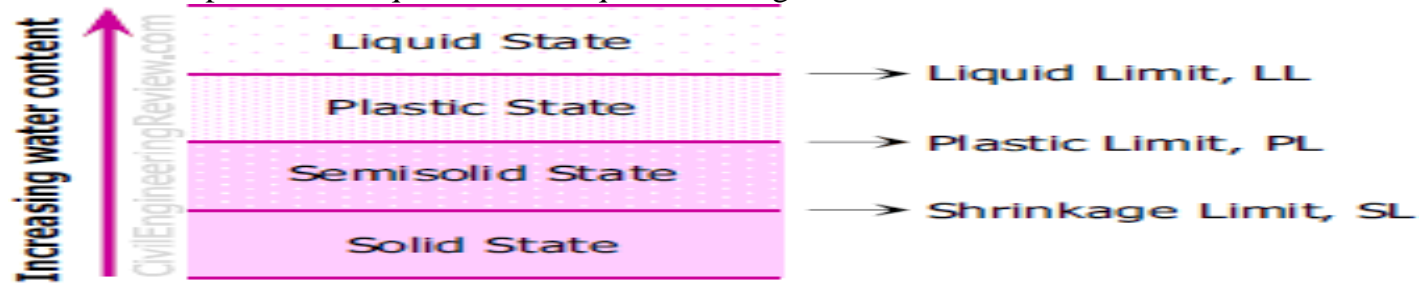

Fig.5 Atterburg limits. Source: Das 2006 
The Atterberg limits are a basic measure of the nature of a fine-grained soil. The Atterberg limits can be used to distinguish between silt and clay, and it can distinguish between different types of silts and clays. These limits were created by Albert Atterberg, a Swedish chemist. They were later refined by Arthur Casagrande (1992). These distinctions in soil are used in picking the soils to build structures on top of. These tests are mainly used on clayey or silty soils since these are the soils that expand and shrink due to moisture content. Clays and silts react with the water and thus change sizes and have varying shear strengths. Thus these tests are used widely in the preliminary stages of building any structure to insure that the soil will have the correct amount of shear strength and not too much change in volume as it expands and shrinks with different moisture contents (Seed, 1967).

Shrinkage limit: The shrinkage limit (SL) is the water content where further loss of moisture will not result in any more volume reduction. The shrinkage limit is much less commonly used than the liquid limit and the plastic limit.

Plastic limit: The plastic limit (PL) is the water content where soil transitions between brittle and plastic behavior. A thread of soil is at its plastic limit when it begins to crumble when rolled to a diameter of $3 \mathrm{~mm}$.

Liquid limit: The liquid limit (LL) is the water content at which a soil changes from plastic to liquid behavior. The importance of the liquid limit test is to classify soils. Different soils have varying liquid limits. Also to find the plasticity index of a soil you need to know the liquid limit and the plastic limit.

Plasticity index: The plasticity index (PI) is a measure of the plasticity of a soil. The plasticity index is the size of the range of water contents where the soil exhibits plastic properties. The PI is the difference between the liquid limit and the plastic limit (PI = LL-PL). Soils with a high PI tend to be clay, those with a lower PI tend to be silt, and those with a PI of 0 (non-plastic) tend to have little or no silt or clay (Das, 2006).

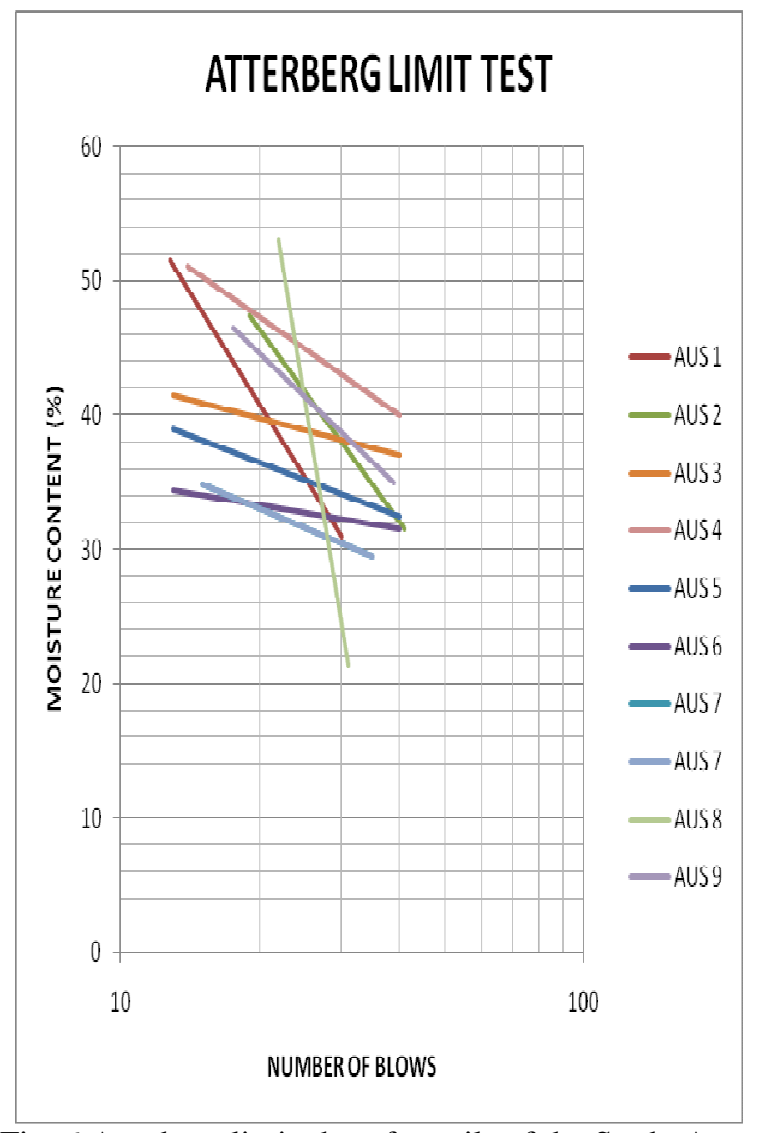

Fig. 6 Atterberg limit chart for soils of the Study Area

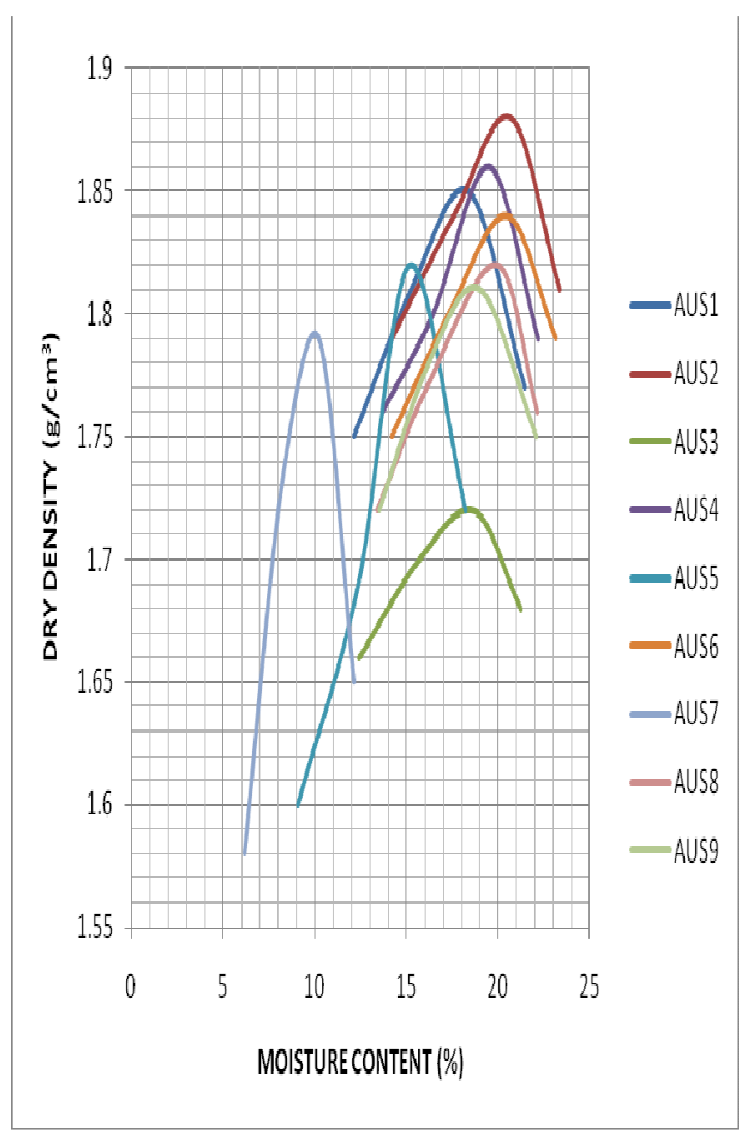

Fig.7 Compaction chart for Soils of the Study Area 
Compaction: A compaction test was carried out on the representative samples by mechanically pressing the soil particles close to each other. In the process of compaction air is expelled from the void space in the soil mass, increasing the mass density. The essence of compaction of the soil is to improve its engineering properties (Lambe 1958).

The water content at which the soil is compacted plays an improtant role in the engineering properties of the soil. Soils compacted at a water content less than the optimum water content generally have a flocculated structure, regardless of the method of compaction (Proctor, 1933). It is adviseable that soils of the study area should not be compacted less than their optimum water content. The different dry densities achieved depends upon the type of soil. In general, coarse - grained soils can be compacted to higher dry density than fine grained soils as observed on samples AUS1, AUS2, AUS4, AUS5, AUS6, and AUS9 on Fig. 7.

The permeability of soil decreases with an inrease in water content on the dry side of the optimum water content (i.e. water content less than optimum). There is an improved orientation of the particles and a corresponding reduction in the size of voids which cause a decrease in permeability. The minimum permeability occurs at or slightly above the optimum water content. After that stage, the permeability slightly increases, but it always remains much less than that on the dry side of the optimum. The slight increase in the dry density is more pronouced than the effect of improved orientation.

If the compactive effort is increased, the permeability of the soil decreases due to increased dry density and better orientation of soil particles ( Lambe, 1958). . Compaction of soil is required for the construction of earth dams, canal embankments, highways, railways and in many other enginneering applications. (see compaction curve in the discussion of result.)

Consolidation: When a saturated soil layer is subjected to a stress increase, the pore water pressure is increased suddenly. In sandy soils that are highly permeable, the drainage caused by the increase in the pore water pressure is completed immediately. Poor water drainage is accompanied by a reduction in the volume of the soil mass, which results in settlement. Because of rapid drainage of the pore water in sandy soils, elastic settlement and consolidation occurs simultaneously (Das, 2006).

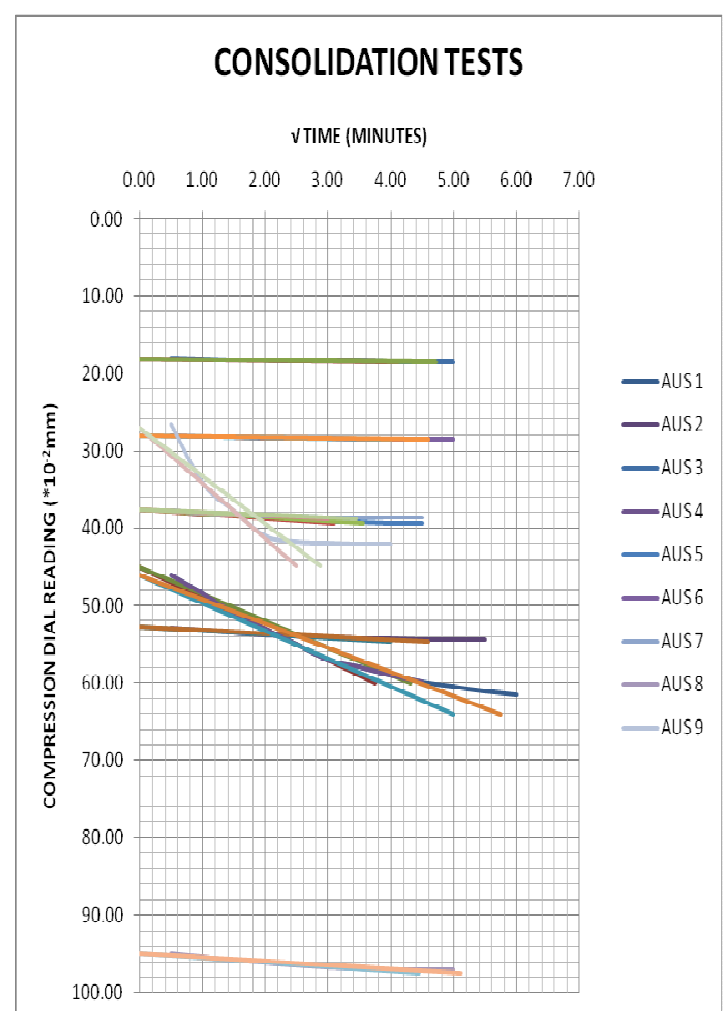

Fig.8. Consolidation Chart for Soils of the Study Area 
Stephen J. Mallo and Alu A.Umbugadu: Continental J. Earth Sciences 7 (1): 40 - 47, 2012

Bulk Density

Table 1: Bulk density for the different soil types

\begin{tabular}{|l|l|l|l|l|l|}
\hline $\begin{array}{l}\text { Sample } \\
\text { No. }\end{array}$ & $\begin{array}{l}\text { Core cutter } \\
\text { Empty } \\
(\mathrm{g})\end{array}$ & Height & Diameter & $\begin{array}{l}\text { Core Cutter }+ \\
\text { Sample } \\
(\mathrm{g})\end{array}$ & $\begin{array}{l}\text { Bulk } \\
\text { Density } \\
\left(\mathrm{KN} / \mathrm{m}^{3}\right)\end{array}$ \\
\hline AUS 1 & 1951.0 & 0.120 & 0.10 & 4130.0 & 21.44 \\
\hline AUS 2 & 1951.0 & 0.120 & 0.10 & 4212.0 & 22.25 \\
\hline AUS 3 & 1951.0 & 0.120 & 0.10 & 3980.0 & 19.96 \\
\hline AUS 4 & 1951.0 & 0.120 & 0.10 & 4170.0 & 21.83 \\
\hline AUS 5 & 1951.0 & 0.120 & 0.10 & 4034.0 & 20.50 \\
\hline AUS 6 & 1951.0 & 0.120 & 0.10 & 4162.0 & 21.76 \\
\hline AUS 7 & 1951.0 & 0.120 & 0.10 & 3912.0 & 19.30 \\
\hline AUS 8 & 1951.0 & 0.120 & 0.10 & 4138.0 & 21.52 \\
\hline AUS 9 & 1951.0 & 0.120 & 0.10 & 4107.0 & 21.21 \\
\hline
\end{tabular}

Table 2.Specific Gravity

\begin{tabular}{|l|l|l|l|l|l|l|}
\hline $\begin{array}{l}\text { Sample } \\
\text { NO }\end{array}$ & $\begin{array}{l}\text { Depth } \\
(\mathrm{m})\end{array}$ & $\begin{array}{l}\mathrm{M}_{1} \\
(\mathrm{~g})\end{array}$ & $\begin{array}{l}\mathrm{M}_{2} \\
(\mathrm{~g})\end{array}$ & $\begin{array}{l}\mathrm{M}_{3} \\
(\mathrm{~g})\end{array}$ & $\begin{array}{l}\mathrm{M}_{4} \\
(\mathrm{~g})\end{array}$ & $\mathrm{Gs}$ \\
\hline AUS 1 & 1.0 & 24.75 & 50.76 & 90.95 & 74.79 & 2.64 \\
\hline AUS 2 & 1.0 & 24.75 & 52.89 & 91.85 & 74.79 & 2.54 \\
\hline AUS 3 & 1.0 & 24.75 & 52.89 & 91.85 & 74.79 & 2.54 \\
\hline AUS 4 & 1.0 & 24.75 & 50.76 & 91.08 & 74.79 & 2.68 \\
\hline AUS 5 & 1.0 & 24.75 & 52.87 & 91.93 & 74.79 & 2.56 \\
\hline AUS 6 & 1.0 & 24.75 & 50.47 & 90.45 & 74.79 & 2.56 \\
\hline AUS 7 & 1.0 & 24.75 & 52.55 & 91.54 & 74.79 & 2.52 \\
\hline AUS 8 & 1.0 & 24.75 & 52.33 & 91.93 & 74.79 & 2.64 \\
\hline AUS 9 & 1.0 & 24.75 & 52.33 & 91.93 & 74.79 & 2.64 \\
\hline
\end{tabular}

WHERE,

$\begin{array}{ll}\mathrm{M}_{1}= & \begin{array}{l}\text { Mass of Density Bottle Empty. } \\ \text { MASS OF DENSITY BOTTLE + DRY SAMPLE }\end{array} \\ \mathrm{M}_{2}= & \text { ONLY. } \\ \mathrm{M}_{3}= & \text { MASS OF DENSITY BOTTLE + SAMPLE + WATER ONLY. } \\ \mathrm{M}_{4}= & \text { MASS OF DENSITY BOTTLE + WATER ONLY. }\end{array}$

\section{DISCUSSION}

The study has become necessary for the purpose of determining the engineering properties of soils of the relatively young state of Nasarawa with all the potential to grow and expand from the metropolitan city of Lafia to Nasarawa Eggon. Ten representative samples were initially taken on a grid of $2,5 \mathrm{~km} \mathrm{x} 2,5 \mathrm{~km}$ from average depths of about 1.25 meters. The samples were subjected to various laboratory tests to determine the geotechnical properties of the soils. The results of the tests have been graphically represented in forms of appropriate charts and tables. The results of geotechnical testing shows Plastic Limit (PL) value of $23.70 \%$ and a corresponding Plasticity Index (PI) of $21.20 \%$. Sieve Analysis indicates particles sizes vary between o.1 to $1.5 \mathrm{~mm}$ with an average summation of between $40 \%-85 \%$ generally indicating medium grained (MG) soil particles (Fig. 4). The compaction tests results carried out on the nine representative samples shows that the dry densities vary from $1.6 \mathrm{~g} / \mathrm{cm} 3$ to a maximum of about $1.86 \mathrm{~g} / \mathrm{cm} 3$; the corresponding range of moisture content being 
Stephen J. Mallo and Alu A.Umbugadu: Continental J. Earth Sciences 7 (1): 40 - 47, 2012

between $7 \%$ to $24 \%$. The compressed Dial reading of the soils $\left(* 10^{2} \mathrm{~mm}\right.$ ) is between 9 and 95 (Figs.6, 7\&8). The highest bulk Density and specific gravity values of soils are $22.25 \mathrm{KN} / \mathrm{m} 2$ and 2.68 respectively.

\section{CONCLUSION}

The study involves some geotechnical testing of soils such as Sieve Analysis, Atterburg Limits (Liquid, Plastic and Shrinkage Limits), Consolidation, Compaction, Bulk Density, and Specific Gravity. While the carrying capacities of soils in some parts of the $48 \mathrm{~km}^{2}$ study area can be affected by increase in moisture content, however the established geotechnical properties indicate that the soil types are generally adequate for civil and foundation engineering constructions. The ultimate destination of this study is to delineate the study area into compartments of similar soil properties for the purpose of utilization in civil and sundry engineering works and / or constructions.

\section{REFERENCES}

Arora, K.R. (2008): Soil Mechanic and Foundation Engineering. Standard Publishers distributors, India. 817 - 837.

Casagrande, A. (1932): “Research of Atterberg Limits of Soils,” Public Roads, Vol.13, No.8, Pp 121 - 136.

Das, M. B. (2006): Principles of Geotechnical Engineering. Cengage Learning, USA ( $6^{\text {th }}$ edition). Pp $15-650$

Falconer, J.D. (1911): The Geography and Geology of Northern Nigeria.Macmillan, London. Pp24 - 25.

Jacobson, R.R.E. and Webb, J.S. (1946): The Pegmatite of Central Nigeria. Geol. Surv. Nig. Bull. No.17. Pp 58 - 66.

Jacobson, R.R.E., Snelling, N.J., and Truswell, J.F. (1964): Age determinations in the Geology of Nigeria with special Reference to the old and Younger Granites. Overseas Geol. Of Mineral Resources. Vol.9, Pp168 - 182

Lambe T. W. (1958): "The Structure of Compacted Clay," Journal of the Soil Mechanics and Founadtions Division, ASCE, Vol.85, No. Sm2 $1654-1$ to $1654-35$.

Macleod, W.N., Turner, D.C., and Wright, E.P. (1971): The Geology of the Jos Plateau. General Geology Bull. Geol. Survey of Nig., number 32, vol.1 Pp122 - 166.

Proctor, R. R. (1933): Fundamentals Principles of Soil Compaction,Engineering News Record (ENR), August 31, Vol. $111, \operatorname{Pp} 9-13$.

Seed, H. B. (1976): Evaluation of Soil Liquefaction Effects on Level GroundDuring Earthquakes, Problems in Geotechnical Engineering, ASCENational Convention, Philadelphia, PA Preprint 2725, Pp 1 - 104.

Turner D.C. (1976): Structural and Petrology of the Younger Granites Ring Complexes. Geology of Nigeria.

Kogbe C. A. (Ed). Elizabethan Press, Lagos Nigeria. Pp 204 - 306

Wright, E. P. (1970): The Basement Complex. Geol. Surv. Nig. Bull. No.32 vol.1.Pp44.

American Society for Testing and Materials (1970). Standard Test Method for Classification of Soils for Engineering Purpose.

American Society for Testing and Materials (2004): Annual Book of ASTM Standards, Sec. 4, Vol. 04.08, West Conshohocken, $\mathrm{Pa}$.

Received for Publication: 19/02/12

Accepted for Publication: 11/04/12

Corresponding author:

Stephen J. Mallo

Department of Geology and Mining, University of Jos, Nigeria 